\title{
Faktor - Faktor Yang Mempengaruhi Prestasi Belajar Mahasiswa Politeknik Negeri Samarinda Dan Implikasi Terhadap Waktu Tunggu Kerja Di Industri
}

\author{
Tandi Kadang ${ }^{1 *}$, Muhtar Sehe ${ }^{2}$, Nita Harnitalia ${ }^{3}$ \\ ${ }^{123}$ Program Studi Administrasi Bisnis, Politeknik Negeri Samarinda, Samarinda 75131 \\ *Correspondent Author \\ E-mail: tandikadang@polnes.ac.id
}

Diterima: 05 Maret 2019 Direvisi: 28 April 2019 Disetujui: 02 Juni 2020

\begin{abstract}
Abstrak
Penelitian untuk menganalisis seberapa besar pengaruh Kualitas Dosen, Fasilitas Pengajaran, Kualitas Pelayanan dan Prestasi Belajar terhadap Waktu Tunggu. Variabel Independen dalam penelitian adalah Kualitas Dosen, Fasilitas Pengajaran, dan Kualitas Pelayanan, sedangkan Prestasi Belajar sebagai variabel Intervening dan Waktu Tunggu sebagai variable dependen adalah Waktu Tunggu. Penelitian ini menggunakan sampel sebanyak 85 Responden dan dilakukan di Politeknik Negeri Samarinda. Penelitian ini menggunakan alat Analisis SEM(Strugtural Equation Modelling) dengan bantuan Software PLS ( Partial Least Square) versi 3.20 dan juga SPSS versi 24. Hasil dari penelitian ini menyatakan bahwa Kualitas Dosen berpengaruh positif tidak signifikan terhadap Prestasi Belajar, selanjutnya fasilitas pengajaran berpengaruh positif tidak signifikan terhadap prestasi belajar, selanjutnya kualitas pelayanan berpengaruh positif signifikan terhadap prestasi belajar, selanjutnya kualitas Dosen berpengaruh positif signifikan terhadap Waktu Tunggu Kerja, selanjutnya Fasilitas Pengajaran berpengaruh positif tidak signifikan terhadap Waktu Tunggu Kerja, selanjutnya Kualitas Pelayanan berpengaruh positif tidak signifikan terhadap Waktu Tunggu Kerja, selanjutnya Prestasi Belajar berpengaruh positif signifikan terhadap Waktu Tunggu Kerja.
\end{abstract}

Kata kunci: Kualitas Dosen, Fasilitas Pengajaran, Kualitas Pelayanan, Waktu Tunggu Kerja

\begin{abstract}
This Research aim was to analyze how much the influence of the Lecturer Quality, Teaching Facilities, Service Quality and Learning Achievement on Waiting Time. The independent variables in the study were Lecturer Quality, Teaching Facilities, and Service Quality, while Learning Achievement as Intervening variable and Waiting Time as the dependent variable. This research used 85 respondents and it was conducted at Samarinda State Polytechnic. This study used SEM (Structural Equation Modeling) analysis tools with the help of PLS (Partial Least Square) software version 3.20 and SPSS version 24.The results of this study stated that the quality of lecturers had a significant positive effect on Learning Achievement, then teaching facilities had a significant positive effect on learning achievement, then the quality of service had a significant positive effect on learning achievement, then the quality of lecturers had a significant positive effect on Working Waiting Time, then Teaching Facilities had no significant positive effect on Working Waiting Time, then Service Quality was not a significant positive effect on Working Waiting Time, then Learning Achievement had a significant positive effect on Work Waiting Time.
\end{abstract}

Keywords: Lecturer Quality, Teaching Facilities, Service Quality, Working Waiting Time 


\section{PENDAhuluan}

Pendidikan merupakan aspek penting dalam kehidupan ini, karena melalui pendidikan seseorang dapat menjadi individu yang lebih berkualitas. Semakin tinggi tingkat pendidikan yang telah ditempuh maka seharusnya semakin berkualitas pula output atau lulusan yang dihasilkan. Salah satu hal yang dapat dijadikan sebagai ukuran kualitas output tersebut adalah bagaimana output ini mampu bersaing di dunia kerja. Pendidikan tinggi merupakan suatu wadah untuk mencetak intelektual yang terampil, memiliki dedikasi yang tinggi, bisa menghadapi kemajuan Iptek dan Imtaq. Kualitas Dosen merupakan hal yang penting. dikarenakan, yang berkualitas yang paling pokok adalah memiliki keahlian penguasaan bidang studi dan keahlian penguasaan metodologi.

Dosen yang berkualitas adalah dosen yang melaksanakan tanggung jawab pengajaran, bimbingan dan latihan keterampilan bagi mahasiswanya. Dosen dalam pelaksanaan pendidikan berkewajiban melaksanakan tugas mengajar dengan memakai perencanaan bahan kuliah, persiapan perkuliahan

Faktor lain yang berpengaruh terhadap prestasi belajar adalah fasilitas pengajaran. Dengan adanya fasilitas pengajaran yang memadai maka akan sangat menunjang proses belajar mengajar diperguruan tinggi , juga kualitas pelayanan perguruan tinggi. Prestasi belajar yang dicapai mahasiswa pada hakekatnyai tidak terlepas dari faktor-faktor yang mempengaruhinya antara lain kualitas dosen, fasilitas pengajaran, kualitas pelayanan diperguruan tinggi tersebut.

Untuk memperoleh suatu pekerjaan dibutuhkan keinginan yang kuat dari segala arah baik itu dari dalam diri maupun dari dorongan berasal dari luar diri. Begitu juga para lulusan Alumni Politeknik Negeri Samarinda haruslah mempunyai motivasi yang kuat dalam mencari kerja.

Maka penelitian ini dilakukan sebagai upaya untuk mengetahui Faktor - Faktor Yang Mempengaruhi Prestasi Belajar Mahasiswa Politeknik Negeri Samarinda Dan Implikasi Terhadap Waktu Tunggu Kerja Di Industri.

Rumusasn masalah yang terdapat dalam penelitian ini yaitu :

1. Apakah $X_{1}$ ( Kualitas Dosen ) berpengaruh signifikan terhadap $Y_{1}$ ( Prestasi Belajar)

2. Apakah $X_{1}$ ( Kualitas Dosen ) berpengaruh signifikan terhadap $Y_{2}$ ( Waktu Tunggu )

3. Apakah $\mathrm{X}_{2}$ ( Alat Bantu dan Fasilitas Pengajaran ) berpengaruh signifikan terhadap $\mathrm{Y}_{1}$ ( Prestasi Belajar)

4. Apakah $\mathrm{X}_{2}$ ( Alat Bantu dan Fasilitas Pengajaran) berpengaruh signifikan terhadap $\mathrm{Y}_{2}$ ( Waktu Tunggu )

5. Apakah $X_{3}$ ( Kualitas Pelayanan ) berpengaruh signifikan terhadap $Y_{1}$ ( Prestasi Belajar )

6. Apakah $\mathrm{X}_{3}$ (Kualitas Pelayanan ) berpengaruh signifikan terhadap $\mathrm{Y}_{2}$ ( Waktu Tunggu )

7. Untuk menganalisis dan membuktikan Y1 ( Prestasi Belajar ) berpengaruh signifikan terhadap Y2 ( Waktu Tunggu )

Kualitas dapat diartikan sebagai "kondisi dinamis yang berhubungan dengan produk, jasa, sumber daya manusia, proses, dan lingkungan yang memenuhi atau melebihi harapan". Berdasarkan definisi ini, kualitas adalah hubungan antara produk dan pelayanan atau jasa yang diberikan kepada konsumen dapat memenuhi harapan dan kepuasan konsumen.

(Tjiptono 2012) Mengatakan bahwa kualitas merupakan: "sebuah kondisi dinamis yang berhubungan dengan produk, jasa, manusia, proses, dan lingkungan yang memenuhi atau melebihi harapan."

Sedangkan dosen adalah pendidik profesional dan ilmuwan dengan tugas utama mentransformasikan, mengembangkan, dan menyebarluaskan ilmu pengetahuan, teknologi, dan seni melalui pendidikan, penelitian, dan pengabdian kepada masyarakat .Fasilitas Pengajaran adalah semua yang diperlukan dalam proses belajar mengajar baik yang bergerak maupun yangtidak bergerak agar pencapaian tujuan pendidikan dapat berjalan dengan lancar, teratur, efektif dan efisien. (Mulyasa 2004) fasilitas pengajaran adalah peralatan dan perlengkapan yang secara langsung dipergunakan dan menunjang proses pendidikan, khususnya dalam proses belajar 
mengajar, seperti gedung, ruang kelas, buku, perpustakaan, laboraturium, meja, kursi, serta alat alat dan media pengajaran lainnya.

Berdasarkan beberapa pendapat diatas, dapat dijelaskan bahwa fasilitas pengajaran adalah perlengkapan belajar yang langsung maupun tidak langsung yang dapat digunakan Dosen untuk memudahkan, melancarkan dan menunjang dalam kegiatan belajar siswa. Dengan adanya fasilitas pembelajaran yang sudah memadai, akan mempengaruhi kreativitas sesorang Dosen pula dalam proses pembelajaran sehingga tercipta pembelajaran yang kreatif dan menyenangkan.

\section{(Lupiyoadi 2014) mengatakan Kualitas adalah perpaduan antara sifat dan karakteristik yang menentukan sejauh mana keluaran dapat memenuhi persyaratan kebutuhan pelanggan, jadi pelanggan yang menentukan dan menilai sampai seberapa jauh sifat dan karakteristik tersebut memenuhi kebutuhannya.}

(Berry, Parasuraman et al. 1994) Mendefinisikan kualitas pelayanan sebagai persepsi pelanggan yang merupakan evaluasi atas sejumlah dimensi - dimensi pelayanan tertentu, seperti: kehandalannya, ketanggapannya, jaminannya, empatinya dan pelayanannya secara fisik. Sedangkan Menurut (Lovelock 1988)yang dikutip oleh (Arli and Tjiptono 2014) "Kualitas pelayanan merupakan tingkat keunggulan (excellent) yang diharapkan dan pengendalian atas keunggulan tersebut untuk memenuhi kebutuhan konsumen".

Menurut (Nasution 2004) "Kualitas pelayanan adalah tingkat keunggulan yang diharapkan dan pengendalian atas tingkat keunggulan tersebut untuk memenuhi keinginan pelanggan"

Berdasarkan pengertian - pengertian diatas, dalam konteks Perguruan Tinggi, maka kualitas pelayanan perguruan tinggi dapat dimaknai persepsi stakeholder yang merupakan evaluasi atas sejumlah dimensi - dimensi pelayanan Perguruan Tinggi.

Prestasi belajar merupakan hasil yang didapat dengan baik pada seorang mahsiswa baik dalam pendidikan atau bidang keilmuan. Mahasiswa memperoleh presatasi belajar dari hasil yang telah dicapai dari proses belajar. Prestasi belajar merupakan hasil pencapaian yang maksimal menurut kemampuan mahasiswa pada waktu tertentu pada sesuatu yang dipelajari, dikerjakan, dimengerti dan diterapkan.

Dalam proses pendidikan prestasi dapat diartikan sebagai hasil dari proses belajar mengajar yakni, penguasaan, perubahan emosional, atau perubahan tingkah laku yang dapat diukur dengan tes tertentu (Abdullah and Muhammad 2008)

Jadi prestasi belajar adalah hasil belajar setelah mengikuti program pembelajaran yang dinyatakan dengan skor atau nilai. Pengukuran akan pencapaian prestasi belajar mahasiswa dalam pendidikan formal telah ditetapkan dalam jangka waktu yang bersifat caturwulan dan sering disebut dengan istilah mid semester (UTS) dan ujian akhir semester (UAS), tetapi dalam prestasi belajar diharapkan adalah peningkatan yang dilakukan dalam materi yang diajarkan.

Kata "waktu tunggu" terdiri dari dua kata yaitu kata "waktu" dan kata "tunggu" yang keduanya mempunyai arti tersendiri. Kata "waktu" berasal dari kata sifat yang artinya waktu yang panjang. Dan kata "tunggu" berasal dari kata yang artinya tinggal sementara untuk berjaga; menanti. Jadi dapat disimpulkan waktu tunggu kerja adalah masa dimana lulusan menunggu untuk mendapat pekerjaan dari awal lulus kuliah hingga mendapat pekerjaan.

\section{METODOLOGI}

Penelitian ini menggunakan penelitian terhadap mahasiswa alumni Politeknik Negeri Samarinda dimana informasi yang didapatkan bersumber dari responden menggunakan Kuesioner..Populasi penelitian ini adalah 85 Responden Alumni Politeknik Negeri Samarinda dengan berbagai Tahun Kelulusan yang berbeda-beda dan Jurusan yang berbeda-beda pula. Teknik pengambilan sampel menggunakan Teknik Stratified Random Sampling adalah pengambilan Anggota Sampel dari populasi dilakukan secara acak dengan memperhatikan strata yang ada dalam populasi itu. Teknik pengumpulan data dalam penelitian ini menggunakan 
accindental random sampling dengan mendistribusikan kuesioner yang dihasilkan oleh beberapa variabel seperti kualitas dosen, fasilitas pengajaran, kualitas pelayanan, prestasi belajar dan waktu tunggu kerja. Kuesioner merupakan teknik pengumpulan data yang dilakukan dengan cara memberi seperangkat pertanyaan tertulis kepada Responden untuk dijawabnya. Dalam hal ini Responden hanya menjawab dengan cara memberi tanda tertentu pada alternatif jawaban yang disediakan. selanjutnya melakukan pengujian istrumen validitas dan realibilitas dengan menggunakan alat analisis yaitu SPSS versi 24 untuk memastikan semua item dari kuesioner sesuai. Sedangkan untuk menganalisis data, instrumen Path Analysis menggunakan alat analisis SmartPLS versi 3.20 dengan langkah-langkah seperti merancang model struktural (model dalam dan luar), membuat diagram jalur, mengubah diagram jalur menjadi regresi, parameter hipotesis, dan menguji hipotesis.

\section{MEMBANGUN DIAGRAM JALUR ( Constructing Path Diagram )}

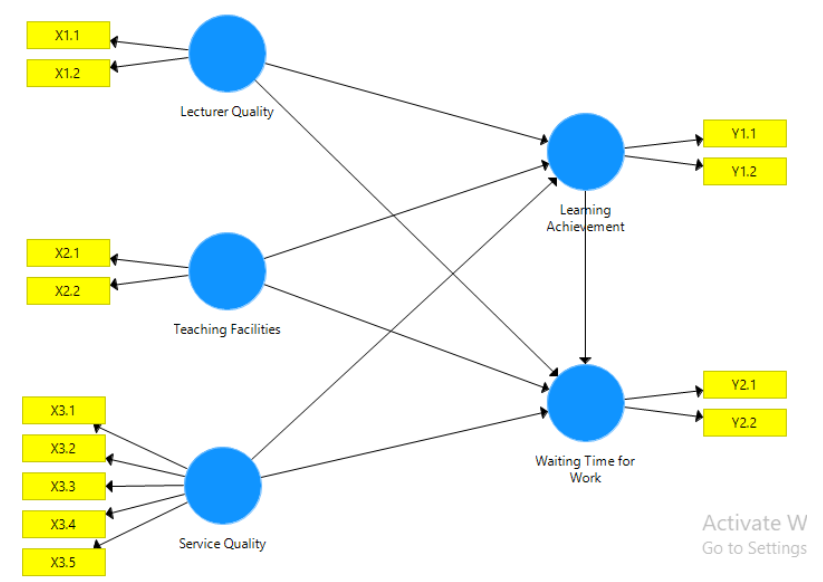

Gambar 1. Constructing Path Diagram

MERANCANG MODEL STRUKTUR ( Designing The Structure Model )

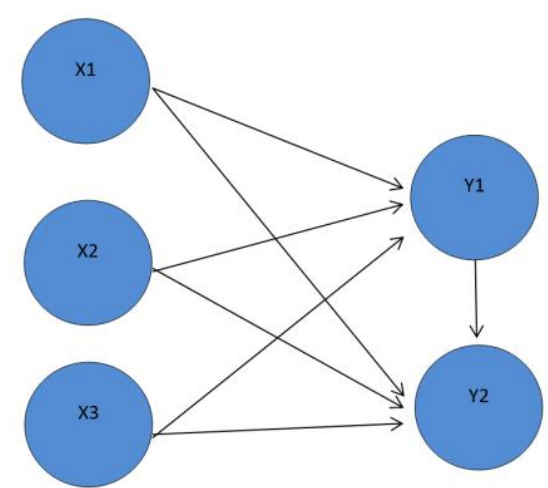

Gambar 2. Designing The Structure Model

Dimana variabel X1 adalah Variable Kualitas Dosen, X2 adalah Variabel Fasilitas Pengajaran, X3 adalah Variabel Kualitas Pelayanan, dan Y1 adalah Variabel Prestasi dan Y2 adalah Variabel Waktu Tunggu Kerja, dari Gambar 1 dapat dijelaskan bahwa $\alpha 1=$ menghubungkan antara variabel $\mathrm{X} 1$ ke $\mathrm{Y} 1, \alpha 2=$ menghubungkan antara variabel $\mathrm{X} 2 \mathrm{ke} \mathrm{Y} 1, \alpha 3=$ menghubungkan antara variabel $\mathrm{X} 3$ ke $\mathrm{Y} 1, \beta 1=$ menghubungkan antara variabel $\mathrm{X} 1 \mathrm{ke} \mathrm{Y} 2, \beta 2=$ menghubunggkan antara 
variabel $\mathrm{X} 2 \mathrm{ke} \mathrm{Y} 2, \beta 3=$ menghubungkan antara variabel $\mathrm{X} 3 \mathrm{ke} \mathrm{Y} 2, \beta 4=$ Menghubungkan antara variabel Y1 ke Y2.

KONVERSI DIAGRAM JALUR KE REGRESI ( Converting Path Diagram to Regression )

$$
\begin{aligned}
& \mathrm{Y} 1=\alpha 1 \mathrm{X} 1+\alpha 2 \mathrm{X} 2+\alpha 3 \mathrm{X} 3+€ 1 \\
& \mathrm{Y} 2=\beta 1 \mathrm{X} 1+\beta 2 \mathrm{X} 2+\beta 3 \mathrm{X} 3+\beta 4 \mathrm{Y} 1+€ 2
\end{aligned}
$$

\section{PARAMETER HIPOTESIS ( Hypthesis Parameter )}

Tingkat keakuratan dari hipotesis ini aadalah $95 \%$ atau alpha $=0,05$. karena hipotesis ini adalah Two tail hipotesis, maka alpha $(\alpha)$ dikonversi menjadi $0,05 / 2=0,025$. Tingkat kebebasan penelitian ini adalah $\mathrm{n}-\mathrm{k}-1$, sedangkan $\mathrm{N}=$ total responden, $\mathrm{K}=$ Total dari variabel, jadi $85-5-$ $1=79$. $\mathrm{T}$ table $(0,025 ; 79)=1,990$. Hipotesis akan diterima apabila $\mathrm{T}$ test $>\mathrm{T}$ table atau $\mathrm{T}$ test $>$ 1,990

\section{Hasil dari hipotesis berikut adalah :}

\section{Hipotesis 1 :}

HO $: \alpha 1=0-\rightarrow$ Jika $\alpha 1=0$, maka Kualitas Dosen tidak berpengaruh terhadap prestasi belajar $H a: \alpha 1 \neq 0-\rightarrow$ Jika $\alpha 1 \neq 0$, maka Kualitas Dosen Berpengaruh terhadap prestasi belajar

Hipotesis 2 :

$H O: \alpha 2=0-\rightarrow$ Jika $\alpha 2=0$, maka fasilits pengajaran tidak signifikan terhadap prestasi belajar $H a: \alpha 2 \neq 0-\rightarrow$ Jika $\alpha 2 \neq 0$, maka fasilitas pengajaran signifikan terhadap prestasi belajar

\section{Hipotesis 3 :}

$H 0: \alpha 3=0-\rightarrow$ Jika $\alpha 3=0$, maka kualitas pelayanan tidak signifikan terhadap prestasi belajar $H a: \alpha 3 \neq 0$ - $\rightarrow$ Jika $\alpha 3 \neq 0$, maka kualitas pelayanan signifikan terhadap prestasi belajar

Hipotesis 4 :

$H 0: \beta 1=0-\rightarrow$ Jika $\beta 1=0$, maka kualitas dosen tidak signifikan terhadap waktu tunggu kerja $H a: \beta 1 \neq 0-\rightarrow$ Jika $\beta 1 \neq 0$, maka kualitas dosen signifikan terhadap waktu tunggu kerja

\section{Hipotesis 5 :}

$H 0: \beta 2=0-\rightarrow$ Jika $\beta 2=0$, maka fasilitas pengajaran tidak signifikan terhadap waktu tunggu kerja

Ha: $\beta 2 \neq 0-\rightarrow$ Jika $\beta 2 \neq 0$, maka fasilitas pengajaran signifikan terhadap waktu tunggu kerja

\section{Hipotesis 6 :}

$H 0: \beta 3=0-\rightarrow$ Jika HO :B3, maka kualitas pelayanan tidak signifikan terhadap waktu tunggu erja

$H a: \beta 3 \neq 0-\rightarrow$ Jika $\beta 3 \neq 0$, maka kualitas pelayanan signifikan terhadap waktu tunggu kerja

Hipotesis 7 :

$H 0: \beta 4=0-\rightarrow$ Jika $\beta 3=0$, maka prestasi belajar tidak signifikan terhadap waktu tunggu kerja $H a: \beta 4 \neq 0-\rightarrow$ Jika $\beta 4 \neq 0$, maka prestasi belajar signifikan terhadap waktu tunggu kerja

\section{HASIL DAN PEMBAHASAN}

\section{UJI VALIDITAS X}

Tabel 1 Uji Validitas X

\begin{tabular}{|c|c|c|}
\hline Items & $\begin{array}{c}\text { Pearson } \\
\text { Correlation }\end{array}$ & Description \\
\hline $\mathrm{X} 1.1$ & 0,509 & Valid \\
\hline $\mathrm{X} 1.2$ & 0,604 & Valid \\
\hline $\mathrm{X} 1.3$ & 0,427 & Valid \\
\hline $\mathrm{X} 1.4$ & 0,533 & Valid \\
\hline
\end{tabular}




\begin{tabular}{|c|c|c|} 
& & \\
X1.5 & 0,567 & Valid \\
\hline X1.6 & 0,357 & Valid \\
\hline X1.7 & 0,57 & Valid \\
\hline X2.1 & 0,725 & Valid \\
\hline X2.2 & 0,776 & Valid \\
\hline X2.3 & 0,761 & Valid \\
\hline X3.1 & 0,811 & Valid \\
\hline X3.2 & 0,761 & Valid \\
\hline X3.3 & 0,668 & Valid \\
\hline X4.1 & 0,746 & Valid \\
\hline X4.2 & 0,669 & Valid \\
\hline X4.3 & 0,791 & Valid \\
\hline X5.1 & 0,687 & Valid \\
\hline X5.2 & 0,785 & Valid \\
\hline X5.3 & 0,724 & Valid \\
\hline X6.1 & 0,804 & Valid \\
\hline X6.2 & 0,663 & Valid \\
\hline X6.3 & 0,674 & Valid \\
\hline X7.1 & 0,755 & Valid \\
\hline X7.2 & 0,721 & Valid \\
\hline X7.3 & 0,755 & Valid \\
\hline GTX & 1 & Valid \\
\hline
\end{tabular}

\section{UJI VALIDITAS Y}

Tabel 2. Uji Validitas Y

\begin{tabular}{|c|c|c|}
\hline Items & $\begin{array}{c}\text { Pearson } \\
\text { Correlation }\end{array}$ & Description \\
\hline Y11 & 0,678 & Valid \\
\hline Y12 & 0,747 & Valid \\
\hline Y13 & 0,682 & Valid \\
\hline Y21 & 0,719 & Valid \\
\hline Y22 & 0,741 & Valid \\
\hline Y23 & 0,612 & Valid \\
\hline GTY & 1 & Valid \\
\hline
\end{tabular}

Berdasarkan data yang diuji, dapat disimpulkan bahwa semua item tersebut adalah valid, dikarenakan semua Korelasi Person (Pearson Correlation) lebih besar dari 0,3.

\section{UJI REABILITAS}

Tabel 3. Uji Realibilitas

\begin{tabular}{|c|c|c|}
\hline Items & $\begin{array}{c}\text { Cronbach's } \\
\text { Alpha }\end{array}$ & Description \\
\hline $\mathrm{X} 1.1$ & 0,948 & Reliabel \\
\hline
\end{tabular}




\begin{tabular}{|l|l|l|}
\hline X1.2 & 0,947 & Reliabel \\
\hline X1.3 & 0,949 & Reliabel \\
\hline X1.4 & 0,948 & Reliabel \\
\hline X1.5 & 0,948 & Reliabel \\
\hline X1.6 & 0,949 & Reliabel \\
\hline X1.7 & 0,948 & Reliabel \\
\hline X2.1 & 0,947 & Reliabel \\
\hline X2.2 & 0,946 & Reliabel \\
\hline X2.3 & 0,947 & Reliabel \\
\hline X3.1 & 0,946 & Reliabel \\
\hline X3.2 & 0,947 & Reliabel \\
\hline X3.3 & 0,948 & Reliabel \\
\hline X4.1 & 0,946 & Reliabel \\
\hline X4.2 & 0,947 & Reliabel \\
\hline X4.3 & 0,946 & Reliabel \\
\hline X5.1 & 0,947 & Reliabel \\
\hline X5.2 & 0,946 & Reliabel \\
\hline X5.3 & 0,947 & Reliabel \\
\hline X6.1 & 0,946 & Reliabel \\
\hline X6.2 & 0,947 & Reliabel \\
\hline X6.3 & 0,947 & Reliabel \\
\hline X7.1 & 0,946 & Reliabel \\
\hline X7.2 & 0,946 & Reliabel \\
\hline X7.3 & 0,946 & Reliabel \\
\hline Y1.1 & 0,948 & Reliabel \\
\hline Y1.2 & 0,949 & Reliabel \\
\hline Y1.3 & 0,949 & Reliabel \\
\hline Y2.1 & 0,949 & Reliabel \\
\hline
\end{tabular}

Berdasarkan data yang diuji, dapat disimpulkan bahwa semua item tersebut adalah realibel, dikarenakan semua Cronbach's Alpha >0,6 HASIL PENELITIAN DAN PEMBAHASANHasil penelitian ini kami menggunakan alat analisis SPSS Versi 24, berikut hasil yang diperoleh

\section{ANALISIS JALUR}

Dengan menggunakan alat analisis Smart PLS versi 3.20, gambar model dengan faktor koefisien (loading factor) dan analisis jalur (path coefficients), dapat ditampilkan seperti dibawah ini : gambar 1 


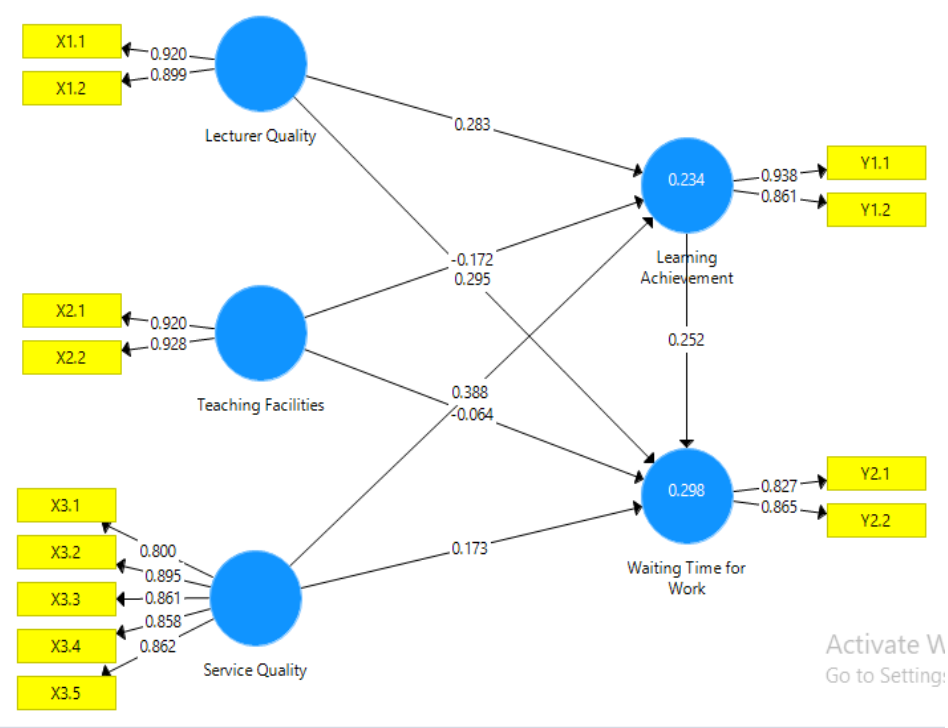

Gambar 3. Model dengan faktor koefisien (loading factor) dan analisis jalur (path coefficients)

\section{Path Coeficient}

Berdasarkan dari Gambar 1 dan Tabel jalur koefisien, model diatas dapat dikonversikan menjadi :

$\mathrm{Y} 1=0.283 \mathrm{X} 1+(-0.172) \mathrm{X} 2+0.388 \mathrm{X} 3$

$\mathrm{Y} 2=0.295 \mathrm{X} 1+(-0.064) \mathrm{X} 2+0.173 \mathrm{X} 3+0.252 \mathrm{Y} 1$

$\mathrm{X} 1.1=0.920 \mathrm{X} 1$

$\mathrm{X} 1.2=0.899 \mathrm{X} 1$

$\mathrm{X} 2.1=0.920 \mathrm{X} 2$

$\mathrm{X} 2.2=0.928 \mathrm{X} 2$

$\mathrm{X} 3.1=0.800 \mathrm{X} 3$

$\mathrm{X} 3.2=0.895 \mathrm{X} 3$

$\mathrm{X} 3.3=0.861 \mathrm{X} 3$

$\mathrm{X} 3.4=0.858 \times 3$

$\mathrm{X} 3.5=0.862 \mathrm{X} 3$

$\mathrm{Y} 1.1=0.938 \mathrm{Y} 1$

$\mathrm{Y} 1.2=0.861 \mathrm{Y} 1$

$\mathrm{Y} 2.1=0.827 \mathrm{Y} 2$

$\mathrm{Y} 2.2=0.865 \mathrm{Y} 2$

\section{Path Coeficient}

Tabel 4. Jalur koefisien (Path Coeficient) dapat ditampilkan sebagai berikut :

Path Coefficients

\begin{tabular}{|c|c|c|c|c|c|c|c|}
\hline \multirow[t]{2}{*}{ Matrix } & \multirow[t]{2}{*}{ 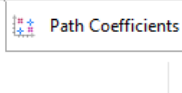 } & \multicolumn{5}{|c|}{ Copy to Clipboard: } & \multirow[t]{2}{*}{ Excel Format } \\
\hline & & Learning Achievement & Lecturer Quality_ & Service Quality & Teaching Facilities & Waiting & \\
\hline \multicolumn{3}{|c|}{ Learning Achievement } & & & & & 0.252 \\
\hline \multicolumn{2}{|c|}{ Lecturer Quality_ } & 0.283 & & & & & 0.295 \\
\hline \multicolumn{2}{|c|}{ Service Quality } & 0.388 & & & & & 0.173 \\
\hline \multicolumn{2}{|c|}{ Teaching Facilities } & -0.172 & & & & & -0.064 \\
\hline
\end{tabular}


Tabel 5. R Square

\begin{tabular}{|c|c|c|c|c|}
\hline \multicolumn{5}{|l|}{ R Square } \\
\hline \multirow[t]{2}{*}{ Matrix } & 灌 & \multicolumn{2}{|c|}{ 茾筆 R Square Adjusted } & \\
\hline & & R Square & & quare Adjustec \\
\hline \multicolumn{2}{|c|}{ Learning Achievement } & 0.234 & & 0.205 \\
\hline \multicolumn{2}{|c|}{ Waiting Time for Work } & 0.298 & & 0.263 \\
\hline
\end{tabular}

Berdasarkan table R Square menyatakan bahwa tingkat pengaruh variabel independen yaitu Kualitas Dosen, Fasilitas Pengajaran, dan Kualitas Pelayanan terhadap Prestasi Belajar sebesar 0.234 atau $23,4 \%$ yang berarti bahwa ada faktor atau variabel lain yang memiliki pengaruh dominan dibandingkan variabel yang digunakan pada penelitian ini yang berpengaruh terhadap Prestasi Belajar. Sedangkan tingkat pengaruh variabel Kualitas Dosen, Fasilitas Pengajaran, Kualitas Layanan, dan Prestasi Belajar terhadap Waktu Tunggu Kerja sebesar 0.298 atau 29,8\%, yang berarti bahwa ada pengaruh variabel lain yang lebih dominan untuk mempengaruhi Waktu Tunggu Kerja dibandingkan dengan variabel yang digunakan pada penelitian ini.

Jadi dapat disimpulkan bahwa variable kualitas pelayanan mempengaruhi secara dominan terhadap Prestasi Mahasiswa POLNES dan implilkasi, waktu tunggu kerja di industri.

\section{PENGUJIAN HIPOTESIS}

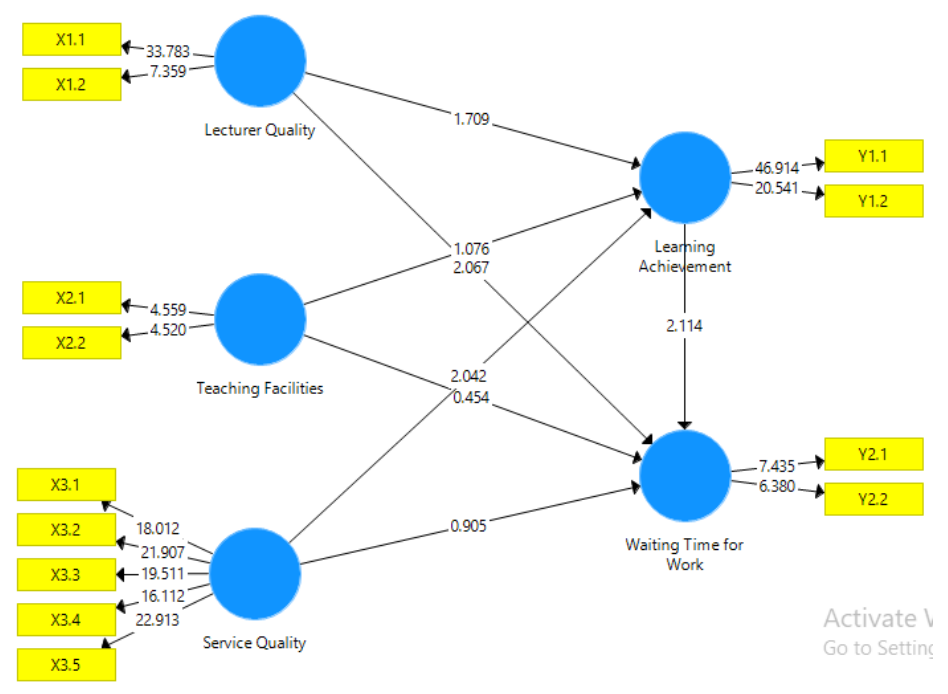

Gambar 4. Model dengan faktor koefisien (loading factor) dan analisis jalur (path coefficients)

Tabel 6. Path Coefficient Total Effects

\begin{tabular}{|c|c|c|c|c|c|c|c|c|}
\hline \multirow[t]{2}{*}{ 圆 Mean, STDEV, T-Values, P-Va... } & Confidence Intervals & 目 & \multicolumn{2}{|c|}{ Confidence Intervals Bias $\mathrm{C} . .}$. & Samples & \multicolumn{2}{|c|}{ Copy to Clipboard: } & Exce \\
\hline & & Original Sample... & . Sample Mean... & \multicolumn{2}{|c|}{ Standard Deviation ... } & T Statistics ... & \multicolumn{2}{|c|}{ P Values } \\
\hline \multicolumn{2}{|c|}{ Learning Achievement $>$ Waiting Time for Work } & 0.252 & 0.238 & & 0.119 & 2.114 & & 0.037 \\
\hline \multicolumn{2}{|c|}{ Lecturer Quality_ -> Learning Achievement } & 0.283 & 0.266 & & 0.165 & 1.709 & & 0.091 \\
\hline \multicolumn{2}{|c|}{ Lecturer Quality_ -> Waiting Time for Work } & 0.366 & 0.356 & & 0.163 & 2.244 & & 0.027 \\
\hline \multicolumn{2}{|c|}{ Service Quality -> Learning Achievement } & 0.388 & 0.376 & & 0.190 & 2.042 & & 0.044 \\
\hline \multicolumn{2}{|c|}{ Service Quality -> Waiting Time for Work } & 0.271 & 0.250 & & 0.182 & 1.488 & & 0.140 \\
\hline \multicolumn{2}{|c|}{ Teaching Facilities -> Learning Achievement } & -0.172 & -0.124 & & 0.160 & 1.076 & & 0.285 \\
\hline \multicolumn{2}{|c|}{ Teaching Facilities $->$ Waiting Time for Work } & -0.108 & -0.075 & & 0.143 & 0.751 & & 0.455 \\
\hline
\end{tabular}


Berdasarkan tabel Path Coefficient menyatakan bahwa Kualitas Dosen berpengaruh positif tidak signifikan terhadap Prestasi Belajar karena nilai T statistic $<$ T tabel yaitu $1.709<1.990$ atau nilai $\mathrm{P}$ value $>0.050$ yaitu $0.091>0.050$, hal ini berarti $\mathrm{H} 0$ pada Hipotesis pertama dapat diterima, selanjutnya fasilitas pengajaran berpengaruh positif tidak signifikan terhadap prestasi belajar karena nilai $\mathrm{T}$ statistic $<\mathrm{T}$ tabel yaitu $1.076<1.990$ atau nilai $\mathrm{P}$ Value $>0.050$ yaitu 0.285 $>0.050$. hal ini berarti H0 pada hipotesis kedua ini dapat diterima.

Selanjutnya kualitas pelayanan berpengaruh positif signifikan terhadap prestasi belajar karena nilai $\mathrm{T}$ statistic $>\mathrm{T}$ tabel yaitu $2.042>1.990$ atau nilai $\mathrm{P}$ Value $<0.050$ yaitu $0.044<$ 0.050. Hal ini berarti $\mathrm{H} 1$ pada hipotesis ketiga ini dapat diterima.

Selanjutnya kualitas Dosen berpengaruh positif signifikan terhadap Waktu Tunggu Kerja karena nilai T statistic $>\mathrm{T}$ tabel yaitu $2.067>1.990$ atau nilai $\mathrm{P}$ Value $<0.050$ yaitu $0.042<$ 0.050. Hal ini berarti $\mathrm{H} 1$ pada hipotesis keempat ini dapat diterima.

Selanjutnya Fasilitas Pengajaran berpengaruh positif tidak signifikan terhadap Waktu Tunggu Kerja karena nilai $\mathrm{T}$ statistic $<\mathrm{T}$ tabel yaitu $0.454<1.990$ atau nilai $\mathrm{P}$ value $>0.050$ yaitu $0.651>0.050$, hal ini berarti H0 pada Hipotesis kelima dapat diterima

Selanjutnya Kualitas Pelayanan berpengaruh positif tidak signifikan terhadap Waktu Tunggu Kerja karena nilai T statistic $<\mathrm{T}$ tabel yaitu $0.905<1.990$ atau nilai $\mathrm{P}$ value $>0.050$ yaitu $0.368>0.050$, hal ini berarti H0 pada Hipotesis keenam dapat diterima

Selanjutnya Prestasi Belajar berpengaruh positif signifikan terhadap Waktu Tunggu Kerja karena nilai T statistic $>\mathrm{T}$ tabel yaitu $2.114>1.990$ atau nilai $\mathrm{P}$ Value $<0.050$ yaitu $0.037<$ 0.050. Hal ini berarti $\mathrm{H} 1$ pada hipotesis ketujuh ini dapat diterima.

Tabel 7. Total inderect effect

Total Indirect Effects

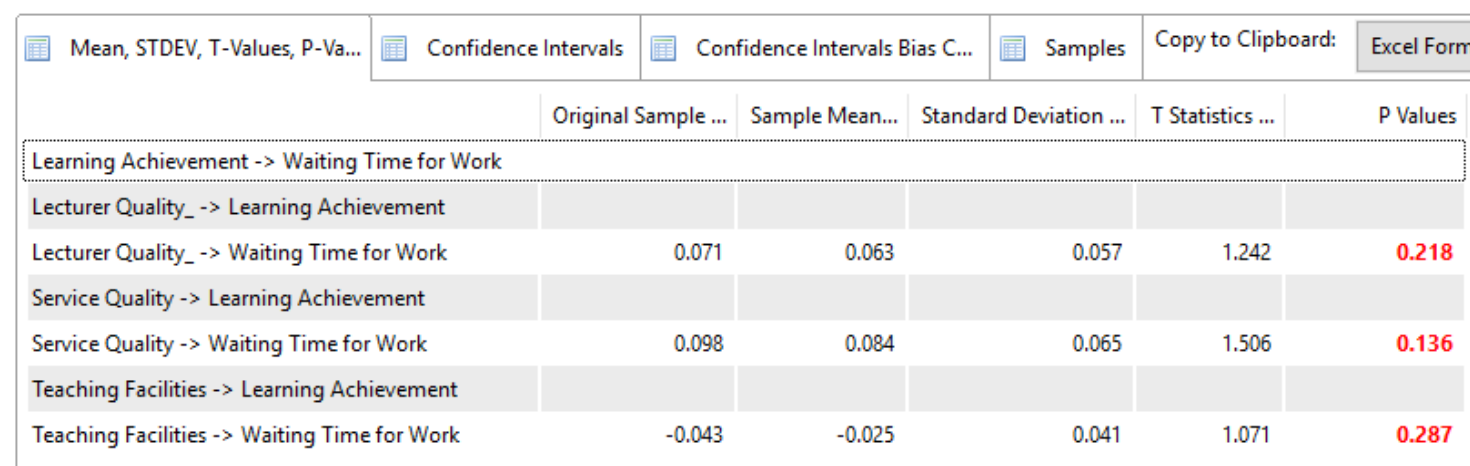

Berdasarkan tabel total inderect effect menyatakan bahwa pengaruh kualitas dosen, fasilitas pengajaran, dan kualitas pelayanan terhadap waktu tunggu kerja di Industri melalui prestasi belajar berpengaruh positif tidak signifikan karena T Statistic ketiga variabel independen $<1.990$ atau $\mathrm{P}$ Value $>0.050$. Hal ini dikarenakan adanya faktor-faktor lain yang mempengaruhi Waktu Tunggu Kerja selain dari ketiga variabel yang digunakan pada penelitian ini

\section{KESIMPULAN}

Kesimpulan dari Penelitian ini adalah Kualitas Dosen berpengaruh positif tidak signifikan terhadap Prestasi Belajar, selanjutnya fasilitas pengajaran berpengaruh positif tidak signifikan terhadap prestasi belajar, selanjutnya kualitas pelayanan berpengaruh positif signifikan terhadap prestasi belajar, selanjutnya kualitas Dosen berpengaruh positif signifikan terhadap Waktu 
Tunggu Kerja, selanjutnya Fasilitas Pengajaran berpengaruh positif tidak signifikan terhadap Waktu Tunggu Kerja, selanjutnya Kualitas Pelayanan berpengaruh positif tidak signifikan terhadap Waktu Tunggu Kerja, selanjutnya Prestasi Belajar berpengaruh positif signifikan terhadap Waktu Tunggu Kerja.

\section{DAFTAR PUSTAKA}

Abdullah, A. M. I. and A. Muhammad (2008). "Prestasi Belajar." Online).(http://Spesialis-Torch. Com/Content/View/120/29/). diakses 5.

Arikunto, S. (2002). "Prof., Dr." Prosedur Penelitian (Suatu Pendekatan Praktek) Edisi Revisi V. Jakarta. Rineka Cipta.

Arikunto, S. (2019). "Manajemen penelitian."

Arli, D. and F. Tjiptono (2014). "Does corporate social responsibility matter to consumers in Indonesia?" Social Responsibility Journal 10(3): 537-549.

Berry, L. L., et al. (1994). "Improving service quality in America: lessons learned." Academy of Management Perspectives 8(2): 32-45.

Deming, W. E. and D. W. Edwards (1982). Quality, productivity, and competitive position, Massachusetts Institute of Technology, Center for advanced engineering study ....

G. Ryder, K. G. (1970). Faculty Raight And Responnsibility San Fransisco. Washington, Jossey.

Kotler, P. and J. Scheff (1997). Standing room only: Strategies for marketing the performing arts, Harvard Business School Press.

Lovelock, C. H. (1988). Managing services: Marketing, operations, and human resources, Pren

Lupiyoadi, R. (2014). "Pemasaran Jasa."

Mulyasa, E. (2004). Manajemen Berbasis Sekolah, PT Remaja Rosdakarya, Bandung.

Nasution, M. N. (2004). "Manajemen jasa terpadu." Bogor: Ghalia Indonesia.

Sugiyono (2008). Metode penelitian pendidikan:(pendekatan kuantitatif, kualitatif dan R $\&$ D), Alfabeta.

Sugiyono, P. (2014). "Populasi dan sampel." Metode Penelitian Kuantitatif, Kualitatif dan R\&D 291: 292.

Suryosubroto, B. (2002). Proses belajar mengajar di sekolah wawasan baru: beberapa metode pendukung dan beberapa komponen layanan khusus, PT Rineka Cipta.

Suyanto, M. (2003). Multimedia alat untuk meningkatkan keunggulan bersaing, Penerbit Andi.

Tjiptono, F. (2004). "Kepuasan dalam Pelayanan." Penerbit Salemba Empat, Jakarta.

Tjiptono, F. (2006). "Manajemen Jasa, edisi pertama." Yogyakarta: Andi.

Tjiptono, F. (2012). "Service Management: Mewujudkan Layanan Prima Edisi 2." Yogyakarta: Andi.

G. Ryder, K. G. (1970). Faculty Raight And Responnsibility San Fransisco. Washington: Jossey. 